Spencer was born at Worcester on July 7, 1870 , the eldest son of James Spencer, for many years headmaster of the Day School Department of Bradford Technical College. According to a note in a local paper on the occasion of his appointment to the British Museum, he was "nurtured on examinations" and "when he had just completed his seventh year he turned his serious attention to geology ....". From Bradford he went with a Royal Exhibition to the Royal College of Science for Ireland, taking a first in chemistry. Thence with a scholarship he went to Sidney Sussex College, Cambridge. He won the Harkness Scholarship in 1893 and successfully competed for a vacancy in the Department of Mineralogy in the British Museum (Natural History) in the same year. He then went for six months to Munich to study under Paul Groth, using his Harkness Scholarship money for the purpose, and returning to take up his appointment at the Museum on January 1, 1894. He married in 1899 Edith Mary, daughter of Islip J. Close, of Mortimer, Berkshire, and leaves a son and two daughters.

Spencer's main achievement in the Department of Mineralogy, apart from his scientific research work, was the establishment of the system of registration, labelling and card-cataloguing the mineral collection. After Prior became keeper in 1909, Spencer did a great part of the registration himself, and one result of his work and of his careful training of those who followed him is that the National Collection of Minerals is now probably the best documented and indexed in the world.

In addition to all his meticulous work on the collection, Spencer's output of original papers was considerable. His publications number well over a hundred and range over a wide field of descriptive mineralogy. He published two books, on minerals and on precious stones, and he translated from the German two large quartos on the same subjects. He took up the study of meteorites after Prior's retirement in 1927 and contributed many papers on this subject to the Mineralogical Magazine.

The discovery of the meteorite craters at Henbury in Australia and Philby's discovery immediately afterwards of the crater at 'Wabar' with its slag-like masses of silica-glass black with included millions of tiny spheres of nickel-iron gave great impetus to Spencer's work in this field and led him also to take up the problem of the origin of tektites. He strongly advocated the theory that tektites are the product of the impact of great meteorites on the Earth's surface, a theory that still finds many supporters but remains unproved. It was his interest in these problems that led him at the age of sixty-four to accompany an expedition into the heart of the Libyan Desert to investigate on the spot the masses of yellow silica-glass discovered in 1932 by P. A. Clayton. He hoped to find a meteorite crater there, but returned with the problem of the origin of the glass still a mystery. Spencer retained a very active interest in meteorites right to the end of his life, and his very last publication on meteorites was a communication in Nature of March 8, 1958.

Spencer's work at the British Museum would have filled the working life of some men, but he seemed always to be doing the work of three. In 1901 he took over the editorship of the Mineralogical Magazine from Miers, and he continued to edit it until the end of 1955 . Previous to 1901 he had catalogued mineralogical papers for the Royal Society Catalogue for 1883-1900, and he continued this for the Inter- national Catalogue of Seientific Literature for 190114. In 1920 the Mineralogical Society commenced publication of Mineralogical Abstracts, and Spencer edited it and prepared more than half the abstracts himself. When he retired he had edited twelve volumes covering thirty-six years. A dinner in his honour was given him by his friends in November 1950 on the completion of his fifty years as editor of the magazine, and he lived to see Mineralogical Abstracts appear in a new format as a joint BritishAmerican publication aiming at a still wider international coverage of the science.

W. Campbeli Smith

\section{Dr. Eric Berkeley Higgins}

Dr. Eric Berkelex Higgins, who died suddenly on April 8 at the age of seventy-three, was an inventor of the classical industrialist type, which pioneered industrialism, and is still not quite extinct. He had the peculiar flair for chemical development which seems to combine art and science. After early success with Dr. Ormandy, he invented the use of nickel formate in the hydrogenation of oils, and found his capitalist in Hamburg, where he was busy getting the process started when the First World War broke out.

Higgins was arrested in November 1914, and became one of a large number of Englishmen collected, under very unpleasant conditions, from all over Germany. These finally arrived in the Ruhleben racing stables at Spandau, where most of them stayed for the duration of the War, under the supervision of neutral diplomats. The American ambassador soon condemned one barrack (twenty-four horse boxes with hayloft above) as unfit for human habitation, so this was handed over to the already very active representatives of the arts and sciences among the prisoners. The scientists included established research men in physics, chemistry and biology, one of whom eventually became a Nobel prizeman. Soon a laboratory for teaching and research in all these branches came into existence, and Higgins was one of its most active spirits. He had arrived at the camp with two young men just gazetted out of Woolwich, with a sound mathematical training but no science. Higgins made them both change to science as a career, and one of them received his knighthood for it.

The power which Higgins had to enthuse gifted youth, and gain their warm personal regard, played no small part in his subsequent success, which culminated in Catomance, Ltd., which he worked up from small beginnings on his inventions in waterproofing and mothproofing materials. When he showed the latter some years ago at a chemical exhibition in London, he directed attention to it by providing a few live moth grubs engaged in chewing wool, with a microphone and loudspeaker which made them audible to visitors. This naturally appealed to the B.B.C. reporter touring the exhibition, and all the world heard the nasty little fellows munching.

Higgins had a mind the energy of which seemed entirely undiminished by several spells of ill-health. $\mathrm{He}$ would be at it hammer and tongs, first at Liverpool making soap, then at Brentford on watersoftening compounds and naphthol $A S$ dyes, then at Welwyn Garden City on the intensive development work which brought prosperity. He enjoyed to the end the affection of the men and women who formed the firm which he created, and all his life-long friends. H. Stafford Hatfield 